\title{
Government-business relations in multilevel systems: the effect of conflict perception on venue choice
}

Article

Accepted Version

Marshall, D. and Bernhagen, P. (2017) Government-business relations in multilevel systems: the effect of conflict perception on venue choice. West European Politics, 40 (5). pp. 981 1003. ISSN 1743-9655 doi:

https://doi.org/10.1080/01402382.2017.1303245 Available at https://centaur.reading.ac.uk/71063/

It is advisable to refer to the publisher's version if you intend to cite from the work. See Guidance on citing.

Published version at: http://dx.doi.org/10.1080/01402382.2017.1303245

To link to this article DOI: http://dx.doi.org/10.1080/01402382.2017.1303245

Publisher: Routledge

All outputs in CentAUR are protected by Intellectual Property Rights law, including copyright law. Copyright and IPR is retained by the creators or other copyright holders. Terms and conditions for use of this material are defined in the End User Agreement.

www.reading.ac.uk/centaur 
Central Archive at the University of Reading

Reading's research outputs online 


\title{
Government-business relations in multi-level systems: The effect of conflict perception on venue choice
}

David Marshall, University of Reading

Patrick Bernhagen, University of Stuttgart

\begin{abstract}
In multilevel systems, organized interests, including business firms, can pursue their political goals at different levels. At the same time, national systems of interest representation provide important incentive structures and normative and institutional contexts for business political behaviour. In this context, business political strategy is guided by firms' perceptions of their relationship with policymakers. If this relationship is under strain in one venue, firms shift their lobbying effort to alternative venues within the political system, subject to constraints reflecting national institutional legacies. Using survey data on 56 large German and British firms, we investigate empirically how perceptions of government-business relations and national systems of interest representation interact to shape the political behaviour of large firms in multilevel systems. Our analysis shows that perceived conflict between firms and public authorities at the national level leads to increased business lobbying at the EU level. We also find that national institutions and types of interest representation shape relative business engagement at the EU level as well as the readiness of firms to shift venue.
\end{abstract}

\section{Key words}

corporate lobbying, venue shopping, multilevel governance, corporatism, governmentbusiness relations 
In multilevel systems, organized interests, including firms, have opportunities to pursue their political goals at different levels of government. This allows them to focus their advocacy effort on institutional venues that they perceive as biased in their favour while avoiding those in which their political standing is poor (Baumgartner and Jones 1993; Beyers and Kerremans 2012; Eising et al. 2017: this volume). At the same time, nation states continue to provide important incentive structures and normative and institutional contexts for business political behaviour. Traditionally, the link between national systems of interest representation and EU lobbying has been conceptualized as the relationship between organized interests, typically business and labour, and national governments (Cowles 2001). The national institutional environment of business-government relations has been defined by the dichotomy of (neo)corporatism and pluralism (Crouch 1985; Schmitter 1974; Siaroff 1999). Firms embedded in corporatist systems have been found to rely on more encompassing groups to represent their interests in the EU and to be less likely to have the institutionalized capacity to lobby on their own (Grant 1993; Greenwood 2003: 23-4). While the EU's system of interest representation has been found to contain corporatist elements (see Falkner 1998; Poletti et al. 2015), the literature overwhelmingly characterizes the EU as more pluralist than corporatist (Coen 1997; Cowles 1998; Cowles 1996; Bennett 1997; Streeck and Schmitter 1991).

The EU's 'elite pluralism' (Coen 1997) has been found to make the EU system more congenial to the political aspirations of firms from pluralist than from corporatist backgrounds (Greenwood 2003: 23-4; Mazey and Richardson 1993: 199). However, more recent research on business lobbying in the EU questions the continued impact of national modes of interest representation and mediation. Analysing the role of corporatism in predicting direct lobbying, Bernhagen and Mitchell (2009: 172) found that 'at the level of the EU such differences no longer matter where business interests are concerned.' In this paper, we propose that the national institutional context continues to shape business political behaviour in the multilevel system of the EU, but in more complex ways than have hitherto been considered. To this end, we focus on an aspect of government-business relations that should matter in the decision process of business lobbyists in any system of interest representation, albeit in different ways: their perception of how good or strained their relationship to policymakers is. Thus, we investigate the extent to which perceptions of conflict between business actors and public authorities lead to venue shifts in lobbying activity. We want to find out whether poor 
perceived relations at the national level prompt firms to increase their lobbying activities at the supranational level and to what extent such strategic behaviour is affected by the national institutional context.

We pursue these questions empirically using survey data on 56 of the largest German and British companies spanning the principal sectors of the European economy. The political activities of large firms are of great empirical and normative significance (Hart 2004). Exercising substantial power over people as workers and consumers, firms are the leading institutions in capitalist society (Hart 2004). Combined with the fact that large firms are present in national and supranational European politics (Coen 1997; 1998) this makes them an important object of study. As Hart (2004: 48) points out, we cannot hope to understand the political role of firms 'merely by studying peak associations or even trade associations, much less interest groups in general.' In the present article, we focus on firms' direct political activities, as opposed to collective action through business associations. Direct business lobbying is a political activity of high and increasing relevance and the object of an established research programme in its own right (Coen 1997; 1998; Hart 2004).

Our two country cases - Germany and the UK - enable us to investigate variation in institutional environments, above all the domestic system of interest representation. The UK represents a pluralist system while Germany represents a moderately corporatist system of interest representation (Siaroff 1999). The two countries also provide substantively significant examples, representing the two largest EU economies that together comprise almost $40 \%$, respectively, of EU GDP (Eurostat 2016) and of the EU's largest 300 companies (Dullforce 2015). Our online survey allows us to measure variables that are notoriously difficult to observe - the political activity of firms and the beliefs and perceptions of in-house business lobbyists. Our analysis shows that perceived conflict between firms and public authorities at the national level leads to increased business lobbying at the EU level. However, the national context shapes relative business engagement at the EU level as well as the readiness of firms to shift venue.

In the next section, we explain theoretically how the quality of government-business relations shapes the lobbying strategies of firms in national and supranational contexts and how this 
relationship is in turn moderated by the national institutional context. Next, we outline our research design, data and analytical strategy. We then present our empirical findings before concluding by discussing the evidence in the light of the literature on business lobbying.

\section{Business lobbying, venue shopping and national systems of interest representation}

Lobbying is one of several types of political activity pursued by firms. Compared with collective action through peak and trade associations, donations to political parties, or attempts to influence the opinion of the public and of other external actors through public campaigning or philanthropic and 'socially responsible' behaviour, direct lobbying is the most instrumental political activity for firms, and one which is rather narrowly targeted on specific benefits for the firm (Hansen and Mitchell 2000; Hillman and Hitt 1999). The literature on business lobbying is centred on a standard profit-maximizing model that provides a simple, general and now familiar account of why firms lobby policymakers: government decisions about how to use coercive powers and distribute resources have important consequences for a firm's revenues and costs (Grier, Munger and Roberts 1994; Stigler 1971). Some of these activities are less common in Europe than in the US, but direct business lobbying is present and growing in the EU and its member states. The EU institutions as well as national governments all legislate on the terms under which goods and services can be produced and traded in the EU, which, if considered a single unit, is the largest economy in the world. It is not surprising, then, to find that these important political venues attract considerable lobbying activity from firms (Rasmussen and Carroll 2014).

Theories of multilevel governance suggest that firms from EU member countries interact with political institutions at both levels (Eising 2004; Kohler-Koch 1997; Marks and Hooghe 2001). In order to influence EU policymaking, these firms can lobby at the EU level or at the national level or both. Unlike firms from outside the EU, they can seek to enlist national governments to represent their interests in EU policy more effectively than firms from non-EU member countries do. Following the national route through the British government and the Council of Ministers has been identified as an important strategy for British businesses (Bennett 1999). In the context of the European End-of Life Automobile Directive, for example, much business 
lobbying was channelled through national governments (Coen 2005: 202-3). Furthermore, some policy struggles of importance to business are fought out at both the national and the EU level. This is obvious in the case of EU directives, which need to be transposed into national law and thus offer opportunities for lobbying at the stage of transposition. Moreover, most EU regulations are implemented by national governments, so that lobbying at the implementation stage of EU policy can also take place at the national level. Therefore, as Coen (1998: 85) pointed out 'firms play a complex multilevel game when seeking to influence the policy process'. While these analyses concern lobbying after a policy decision is taken at the EU level, others point to multilevel venue shopping (Eising et al. 2017: this volume; KohlerKoch 1997; Kohler-Koch et al. 2017: this volume; Young and Wallace 2000). And finally, there is what Chari and Cavatorta (2002) define as 'overlap issues' i.e. 'issues where two separate, but related, domestic and supranational decisions must be taken because they fall within each level's jurisdiction.' Thus, EU firms can lobby at multiple levels simultaneously, and large European firms frequently engage in multilevel lobbying games to influence the European policy process.

However, given budget and reputation constraints, rather than playing all relevant institutional fields at once, firms and other organised interests have incentives to deploy their political resources strategically (Eising 2004). This involves seeking out institutional venues they perceive as biased in their favour and avoiding those in which their political standing is poor. One strategy for dealing with such biases is to 'shop' for an alternative venue and attempt to move decision-making authority to a different policy arena. In the words of Baumgartner and Jones (1991: 1045), political actors 'try to alter the roster of participants who are involved in the issue by seeking out the most favourable venue for consideration of these issues.' If successful, a change in venue can lead to desired policy change (or, as the case may be, help to preserve a preferred status quo). According to Mazey and Richardson (2001: 220), political integration in Europe has created a quite new opportunity for venue shopping by national and cross-national interest group actors in Europe. Indeed, they argued that venue shopping 'is part of the explanation for the (undisputed) growth in EC/EU level interest group formation and lobbying' (Mazey and Richardson 2001: 220). While Baumgartner and Jones developed the concept of venue shopping for the analysis of public policymaking in the US, Mazey and Richardson (2001) maintain that the EU's system of 
multiple access points created by institutionalised multilevel governance makes venue shopping a fruitful analytical lens for the analysis of lobbying in this polity. Others agree in principle but point out an important difference: in the multilevel system of the EU, where different institutions at different levels of government are involved in the policy process, venue shopping takes the form of concentrating the lobby effort on one of several possible levels without actually shifting decision-making to different venues (Beyers and Kerremans 2012). As Princen and Kerremans (2008: 1139) put it, 'Interest groups may choose between venues but the venues themselves are given'. Moreover, while the US literature has been dominated by analyses of horizontal shifts at one and the same level of government (see Holyoke. 2012 for an overview), the political system of the EU is more encouraging of vertical venue shifts between levels of government. The analysis that follows is concerned with the logic behind these vertical venue shifts.

For large firms, incentives to shift lobbying efforts to different venues can stem from changes in the political standing of firms within the political system. Firstly, for business as a whole, the public mood may be more sympathetic or less. For example, when citizens and policymakers perceive the economy as doing well, they may be more willing to demand policies that are costly to business. This explains part of the 'fluctuating fortunes' of business over time (Vogel 1989). Secondly, different sectors are affected to different degrees by public decision-making (Grier, Munger and Roberts 1994), and at any given time some sectors enjoy better relations with policymakers than others. And thirdly, individual firms may find their relationship with policymakers more or less conducive to their political goals, where this relationship may be shaped by past interactions with policymakers or the extent to which firms have been subject to individual administrative decisions, e.g. in the field of competition policy and merger control, commercial supervision, licencing, or procurement. As Holyoke (2003: 326) pointed out, '[b]because each venue contains a different set of government officials, the quality of the relationships between a group's lobbyist and these policymakers is likely to vary from venue to venue.' Jointly, these factors determine the degree of attractiveness of a political market, which, according to Bonardi, Hillman and Keim (2005: 398) accounts for why a firm engages in political activities. Thus, firms have incentives to shift their political effort away from venues where government-business relations are conflictual to those venues were these relations are more harmonic. 
Proposition 1: As national government-business relations deteriorate; firms increase their lobbying at the EU level relative to national-level lobbying.

However, it would be overly simplistic to expect firms headquartered in different countries and systems of interest representation to make strategic choices among multiple venues independently of the wider political context and the opportunities and constraints that this presents. Firms, like other political actors, are 'embedded' in social relations (Granovetter 1992). As a result, enduring differences can be observed among types of national capitalisms, which ensure that strategies in areas such as research and development, financing, and internal corporate governance remain nationally distinct. With respect to these areas, Pauly and Reich (1997: 1) report that 'recent evidence shows little blurring or convergence at the cores of firms based in Germany, Japan, or the United States'. We submit that these national differences extend to business political strategies too. Holding the political venue constant, implications of such embeddedness have been explored with respect to the political behaviour of affiliates of foreign corporations in Washington DC (Rehbein 1995) and Brussels (Bernhagen and Mitchell 2009; Coen 2005; Grant 1993). While Grant (1993: 171-2) found enduring differences between British and German firms, Rehbein (1995) reports strong similarities between the political strategies of foreign-owned and domestic firms. Similarly, Bernhagen and Mitchell (2009) found little support for the continued role of nationally distinct types of interest representation.

These contradictory and seemingly time-sensitive findings call for more careful theorizing of the moderating role played by the institutional context. Political scientists have devoted years of research to identifying and classifying systems of interest representation and drawing out the political and economic consequences for these different systems and the actors operating within them (see Siaroff 1999 for a summary). The upshot from this conceptual work is widespread agreement that systems of interest representation possess multiple dimensions reflecting both interest group characteristics and policy process characteristics. In spite of ongoing debate about the precise conceptual boundaries and measurement of this aspect of political-economic integration, the theoretical rationale for these concepts is well established and its empirical applications have confirmed the robustness of the measurements used 
(Siaroff 1999; Lijphart 1999). Corporatist systems are characterized by relatively few, centralized and monopolistic interests with good access to the policymaking process and a disposition to compromise and bargain rather than maximize in the policy struggle. Typical examples include Austria, Sweden, and Germany. Pluralist systems, by contrast, have numerous and competitive organised interests all struggling for access to policymakers. Examples include the United States, United Kingdom, and Australia. These differences have implications for unmediated firm lobbying generated by different national contexts. At the national level, more corporatist systems are characterized by a relatively low frequency of individual firm lobbying. Interests are centralized and monopolistic and the policy process characterized by national bargaining between the government, representatives of business and representatives of labour.

This logic extends to other policy arenas. While the EU's system of interest representation has been found to contain corporatist elements (see Falkner 1998; Poletti et al. 2015), these lack the quasi-public functions assigned to major interest groups in a corporatist setting. The most important socioeconomic decisions are still made at the national level or subject to national veto (Lijphart 1999: 44); and the European Economic and Social Committee has a purely advisory role. Accordingly, the EU is widely characterized as an 'elite pluralist arrangement between institutions and policy actors' (Coen, 1997, see also Cowles 1998; Cowles 1996; Bennett 1997; Streeck and Schmitter 1991). In this environment, firms from pluralist systems that had developed the institutional capacity and experience to represent their own interests were argued to be well positioned for lobbying in the European policy arena: 'Anglo and American firms in particular, familiar with operating in pluralist environments, are used to operating outside groups ... whereas those used to the corporatist traditions of Germanic countries tend to place greater emphasis upon associations' (Greenwood 2003: 23-4). Similarly, Mazey and Richardson (1993: 199) found that, alongside American groups, British organisations were 'widely regarded as being among the most enthusiastic EC lobbyists'. By contrast, firms embedded in highly corporatist systems rely more heavily on encompassing groups to represent their interests in the EU and are less likely to develop the institutionalized capacity to lobby on their own. Thus, twenty years ago, Grant (1993: 15) noted that, in comparison to the US and the UK where firms have developed government relations offices, '[g]overnment relations divisions are relatively unknown in Germany'. 
However, the findings by Bernhagen and Mitchell (2009) suggest that firms from corporatist systems have caught up with the EU lobbying activity of their peers from pluralist systems. If this is an ongoing trend, another decade on we might now see firms from corporatist countries be even more inclined to lobby at the EU level than their peers from pluralist political economies. Moreover, it has been argued that corporatism makes EU-level interest representation more attractive to business in relative terms, because it empowers countervailing interests at the national level (Hix 2005: 265; see also Marks and McAdam 1996 for a similar argument). As corporatism gives organized labour a permanent seat at the bargaining table and easy access to policymakers, it provides business interests with incentives to shift policy debates away from the national level. Both arguments imply that firms from countries with corporatist systems of interest representation have now greater incentives to lobby at the EU level.

Proposition 2: Firms headquartered in corporatist countries place a greater emphasis on EU level lobbying relative to national level lobbying than firms from pluralist countries.

While national systems of interest representation and the incentives they provide for business political strategies have been changing, their basic structures endure. Moreover, a lasting effect has been that the late developers from corporatist countries have had to develop greater flexibility and a broader strategic action repertoire compared to their pluralist peers. The latter's institutional background had already equipped them rather well for lobbying in the context of the EU's élite pluralism (Coen 1997), thus demanding little ability to develop adaptation skills. These differences in the institutional context of German and British firms affect the way in which firms decide to switch venues when facing less than harmonic government-business relations at the national level of the home country.

However, the fact that large firms from pluralist systems are significant players in EU policymaking (Bernhagen and Mitchell 2009; Greenwood 2007; Mazey and Richardson 1993) suggests that there must be circumstances under which these firms shift lobbying activity to the EU level the same way firms from corporatist systems do. As Princen and Kerremans (2008: 1137) point out, venue shopping is not a cost-free activity. Moreover, policy advocates 
may 'stick to national institutional venues because they lack strong institutional allies at the EU level' (Princen and Kerremans 2008: 1137). While for British firms the perception of conflict at the national level is not a sufficient condition to switch lobbying venues, they might do so in circumstances when a relatively supportive policy environment can be expected at the EU level (see Eising et al. 2017: this volume; Kohler-Koch et al. 2017: this volume). This rationale and its behavioural implications apply to firms from pluralist and corporatist systems alike. However, only for the former is it a necessary condition for changing venue.

Proposition 3: Firms from pluralist countries are less ready than firms from corporatist countries to abandon the national route in favour of EU lobbying when national government-business relations deteriorate.

By contrast, pull as well as push factors should play a similar role for firms from any system of interest representation. Ehrlich and Jones (2016) argue that firms located in countries where it is more costly for them to lobby are more likely to lobby at the EU level. These authors expect that 'the more receptive access points are, on average, to a particular interest, the cheaper lobbying will be for that interest and, thus, the more that interest should lobby' $(2016,473)$. We generalize this expectation and argue that firms decide to directly lobby the EU when doing so promises to be relatively more beneficial to them than lobbying at the national level. Thus, when taking into account how welcoming the target venue is expected to be by the firm considering a venue shift, we expect

Proposition 4: Firms from any system of interest representation transfer their lobbying effort from the national to the EU level in response to increases in national conflict relative to that found at the EU level.

\section{Data and Research Strategy}

To evaluate these propositions empirically, we collected information on the political activities for a sample of 56 large corporations headquartered in Germany and the UK in late 2015 and 2016. While the data we can use to evaluate our positions thus consist of cross-sectional 
measurements at a single point in time, a certain temporal order is implied in the theoretical argument presented above. While social scientists tend to think of causality in terms changes in $\mathrm{X}$ producing changes in $\mathrm{Y}$, covariation between these two variables can also be the result of a third process in which some third factor, perhaps in existence prior to both $X$ and $Y$, causes changes in the association between $X$ and $Y$ (Miller 1999: 121). Working with cross-sectional data we evaluate our causal arguments with the aid of observable implications of a crosssectional nature. To this end, we derive the following testable hypotheses about statistical associations in cross-sectional data from our four propositions above:

H1: The more conflictual government-business relations are at the national level, the more firms lobby at the EU level relative to the national level.

H2: Firms headquartered in Germany place a relatively greater emphasis on EU-level lobbying than firms headquartered in the UK.

H3: The effect of conflictual government-business relations at the national level on relative EU lobbying is greater for German firms than for British firms.

$\mathrm{H} 4$ : For firms from both countries, there is a positive association between relative EU lobbying and national conflict relative to EU-level conflict.

The country selection enables us to assess the effects of corporatist and pluralist systems of interest representation. ${ }^{1}$ The sample was drawn in 2013 from Standard \& Poor's Capital IQ database. The database contains financial and structural data on about 70,000 publically traded and more than 700,000 privately owned companies from all over the world. From this source, which served as our population frame, we sampled the 100 largest corporations, respectively, from each of the two countries. ${ }^{2}$ For this purpose, we have created a size ranking based on the average of rankings by revenues, profits, assets and employee numbers. ${ }^{3}$ To obtain data on the political activities of large firms in the context of domestic and European policymaking we have used an online survey of senior managers in the firms' corporate public affairs and public relations departments. Through a lengthy process of online searches and telephone enquiries, we obtained contact details, including email addresses, for 146 senior 
personnel. To maximise response rates, we then sent a hand-signed letter to the personal work address of each potential respondent. This was followed up with an email invitation containing a link to the survey and, in many cases, several reminders by email and telephone. The questionnaire was in the field from $7^{\text {th }}$ December, 2015 until $18^{\text {th }}$ May, 2016. In the end, we received 56 complete or almost complete questionnaires, yielding a response rate of $40 \%$. The response rates in the two countries was quite similar, with our final sample of 56 split into 29 German and 27 British firms.

Through the survey we identified lobbying behaviour and are able to estimate variation across the two countries and for different levels of governance (national and EU). To determine firms' relative engagement across national and EU levels of governance, we asked: 'thinking generally about your company's engagement with policymakers, approximately what percentage of your company's advocacy time is spent' at a number of venues including 'EU institutions' and 'at the national government of country where your company is headquartered'. ${ }^{4}$ To measure relative EU lobbying we divided the percentage of lobbying time a firm devotes to EU lobbying by the sum of the percentages of national (HQ) and EU lobbying $\left(\frac{\% \text { EU lobbying }}{\% \text { National lobbying }+\% E U \text { lobbying }}\right)$. This variable can range from 0 to 100 , where a value of ' 0 ' would indicate that a firm only engages in national lobbying (HQ). The distribution of this variable is shown in Figure 1.

[Figure 1 about here]

Central to the assessment of our theoretical claims is the measurement of the perceived quality of the relationship between the firm and policymakers at both the national and EU level. To gauge this we asked respondents, 'in general, how would you characterise the relationship between your company and public authorities at the national, regional (European Union) levels?' Five response categories were provided: very cooperative, moderately cooperative, neither co-operative nor conflictual, moderately conflictual, and very conflictual, with 1 representing a very cooperative relationship and 5 a very conflictual one. The actual values range from 1 to 4 with a mean of 2.3. In addition, as we are also interested in the relative quality of government-business relations across national and EU levels, we calculate a measure of 'relative conflict'. This was created by dividing the difference between the 
variable 'national conflict' and a corresponding measure of EU conflict by the total of the two measures: $\left(\frac{\text { National conflict }-E U \text { conflict }}{\text { National conflict }+E U \text { conflict }}\right)$. Here higher values indicate greater national conflict relative to that encountered at the EU level, with a value of zero (the actual mean) representing no difference in conflict across venues.

When estimating the hypothesized associations, we need to take account of other factors that may shape firm lobbying at different levels of government and their ability to shift venues when circumstances recommend doing so. Large firms with a stake in the policy issue and the size to attract the attention of regulators are generally more likely to lobby than smaller ones (Boies 1989; Grier, Munger and Roberts 1994). They will also be more likely to lobby at different levels of government and better able to shift resources between venues if they need to. Thus, we take into account the possibility that lobbying behaviour varies according to company size, even within a sample of large companies. To measure firm size, we follow established practice in the literature by taking the natural log of revenues in million US Dollars for the financial year 2015 (Dullforce 2015).

Furthermore, as mentioned above firms' incentives to become politically active in a particular venue differ by industry sector. At the point of conducting the survey an extensive amount of post-crisis financial regulation had just been passed, with a considerable amount of regulatory detail left to finalise - increasing the incentives for firms in the financial sector to engage in EU level lobbying. Therefore, we control for industrial sector by incorporating an indicator for 'financial sector'. ${ }^{5}$ Finally, given that the majority of the largest German and British firms have significant international markets and that many operate large offshore facilities, differences in internationalisation may affect the ability of firms to vary their lobby efforts between venues. To obtain a measure of international political engagement we return to the aforementioned question on the time firms spend across lobbying venues. From the responses we construct a measure of 'foreign CPA (corporate political action)' - defined as the percentage of time spent lobbying 'national governments of other countries in which your company has facilities, markets and/or suppliers'. Empirically, this variable ranges from 0 to 75 and has a mean of $19 .{ }^{6}$ Table $A 1$ in the appendix lists summary statistics of all variables. 


\section{Results}

As the data are new, we begin with descriptive overviews of the variables and associations of interest. First we consider the mode of interest representation through which firms express their positions to policymakers. Of particular interest is whether companies now routinely take a direct approach, which suggests a weakening of corporatist modes of encompassing interest group representation (Bernhagen and Mitchell 2009). Our survey data show that the overwhelming majority of firms within our sample (44 out of 56) reported that they directly approached policymakers. ${ }^{7}$ Furthermore, all these firms stated that they had a government relations unit. As Figure 2 illustrates, German companies are as likely to approach policymakers directly as they are via a trade association, which means they pursue a dual strategy of interest representation. ${ }^{8}$ Nevertheless, there are differences in German and British lobbying practices: while UK firms also frequently use the trade associations avenue, for them the direct approach is the dominant strategy. The use of consultants, finally, features in UK firms' strategy of engagement, while this mode of interest representation is virtually absent in the German part of the sample.

[Figure 2 about here]

This picture remains largely intact when we compare the mode of interest representation by country and across policy types. For this, we coded responses across the 19 specific policy areas, for which firms were asked to indicate their activity, into either regulatory or nonregulatory policy. The patterns shown in Figure 3 indicate that there is only limited variation across policy types, with the exception of UK direct lobbying, which is more pronounced for regulatory policies than for non-regulatory policies.

[Figure 3 about here]

The analysis shown in Figures 4 addresses the question of which level of governance large firms direct their lobbying activity towards. The distinction, according to the literature is between firms lobbying the policymaking institutions of their country of headquarter and of the EU (Bennett 1999; Bernhagen and Mitchell 2009; Grant 1993). The comparison suggests 
that, while the national arena is an important lobbying venue for firms from both countries, the propensity for firms to target the national level rather than the European level is much more pronounced for British firms. While German firms are roughly equally active at the national (country of headquarter) and EU levels, British firms are more than twice as active at the national level than they are at the EU level. This lends initial support to Hypothesis 2.

[Figure 4 about here]

The analysis so far has highlighted important and enduring differences between German and British business lobbying practises, as well as likely areas of convergence. However, as we argue in this paper, when firms engage with policymakers in order to achieve favourable outcomes, the quality of the government-business relationship is likely to be critical to achieving these goals. Therefore, as hypothesised $(\mathrm{H} 1)$, when government-business relations are poor at the national level the likelihood of firms shifting lobbying attention to the EU level will increase. Figure 5 shows mean levels of respondents' perceived conflict with policymakers at the national and EU level, respectively. Higher values indicating greater levels of conflict, and lower levels corresponding to a more cooperative relationship. According to our data, there is no significant difference between British and German firms, whose mean levels of conflict perception range from 2.1 to 2.3 for both levels of government, with identical median scores of 2 . While average perceptions indicate moderately cooperative to neutral relationships, there is considerable variation among firms (see appendix A1) and only a weak correlation between national and EU levels of conflict $(-0.175)$.

[Figure 5 about here]

To address our hypotheses directly, we estimate three multivariate regression models with bootstrapped standard errors, and firms' relative EU lobbying (compared to the national level) as the dependent variable (see Table 1). All models include variables controlling for firm size (revenue (log)), financial sector and foreign CPA. The expectation from Hypothesis 1 is that the more conflictual government-business relations are at the national level, the more firms lobby at the EU level relative to the national level. This expectation finds support in Model 1, where the coefficient for national conflict is positive and statistically significant. A one-unit 
increase in the 5-point scale of national conflict is associated with an increase in EU lobbying of 8.3 percentage points relative to all EU and national (HQ) level lobbying, which represents an effect of considerable magnitude.

[Table 1 about here]

The expectation from Hypothesis 2 is that German firms place relatively greater emphasis on EU lobbying than British firms. In addition to the bivariate analysis presented in Figure 4, the country coefficient in Model 1 is statistically significant and in the expected direction, providing further support for Hypothesis 2. According to the estimate for Model 1, the proportion of time spent on EU lobbying relative to national-level lobbying is 21.5 percentage points lower for UK firms than for German firms. Of the control variables, the coefficient for foreign CPA is significant and in a positive direction. This suggests that the more a firm lobbies across borders the more freely it engages at the supranational level.

In Model 2 we analyse the interaction between national conflict and country (UK = 1, Germany $=0$ ) in order to test whether the effect of conflictual government-business relations at the national level on relative EU lobbying is greater for German firms than for British firms (H3). The coefficient for the interaction term is negative and statistically significant. To aid interpretation, Figure 6 shows how the effect of national conflict on relative EU lobbying is conditional on the national context, with bars representing the $95 \%$ confidence intervals. As the perceived level of national conflict with policymakers increases, German firms shift their lobbying effort from the national to the EU level, whereas increased levels of national conflict show no association with the relative lobby effort expended by British firms at the EU level. At the lower levels of domestic conflict, the ratio of EU to national lobbying is similar for firms from both countries.

[Figure 6 about here]

To estimate whether there is a positive association for firms from both countries between relative EU lobbying and national conflict relative to EU-level conflict (H4), in Model 3 we interact relative conflict and country. The interaction effect is not statistically significant, 
indicating that there is no slope difference between the two countries. This supports Hypothesis 4. To facilitate interpretation, we illustrate this effect in Figure 7. Taken together the estimates for the two interactions in Models 2 and 3 support the argument behind Hypotheses 3 and 4 . While German firms shift venues in response to conflict, this is not a sufficient condition for British firms, who require greater certainty that shifting venues will lead to interactions with a more sympathetic policymaker (Proposition 4).

[Figure 7 about here]

\section{Conclusion}

We have argued that firms adapt their lobby strategies to changes in their political environment by shifting activities away from a venue with conflictual government-business relations to alternative venues (Proposition 1). We have also argued that these shifts take place within nationally distinct contexts represented by corporatist and pluralist political economic systems. In the contemporary EU, these make business lobbying at the EU level more attractive for firms from corporatist countries than for their pluralist counterparts (Proposition 2). These findings provide evidence for a process of change that has unfolded over the past quarter century. While Grant (1993) and others found direct firm lobbying at the level of the $E C / E U$ to be dominated by firms from the pluralist systems of interest representation of the Anglo-Saxon world, Bernhagen and Mitchell (2009) found that by 2005 differences in lobby behaviour between firms from pluralist and corporatist backgrounds had disappeared. Another decade later, the original difference seems to be reversed: according to our 2015 survey data, UK firms are more likely to lobby their national government while German firm are more likely to engage at the EU level.

Moreover, the ability of firms to shift venues as the need arises is taken up more readily by firms from a corporatist background, who over the past 30 years have accumulated experience in both, negotiating multilevel political environments and adapting from corporatist to pluralist contexts (Proposition 3). This provides them with a strategic advantage over firms from the pluralist background of the UK, who did not expend great effort at 
adapting to the supranational policy arena of the EU, as both, national pluralism and the EU'S system of interest representation encourage direct firm lobbying. Finally, we argued that differences between firms from pluralist and corporatist backgrounds should disappear when the quality of government-business relations at the EU level is taken into account in addition to the level of national conflict, because the calculus of relative conflict is shared by firms from both systems (Proposition 3). Our statistical analysis of firm-level survey data supports these propositions. Thus, we can infer that perceived conflict between firms and public authorities at the national level leads to increased business lobbying at the EU level. Moreover, while national institutions and types of interest representation shape relative business engagement at the EU level as well as the readiness of firms to shift venue, firms from any background seek to abandon conflictual lobbying environments if alternative venues look more promising.

The analysis reported in this article contributes to the literatures on business lobbying and venue shopping in four principal ways: First, our findings support the claim by Bonardi, Hillman and Keim (2005) that the degree of attractiveness of a political market accounts for the extent to which a firm engages in political activities within that arena. By showing that firms from a pluralist background, unlike their corporatist peers, are willing to reduce political engagement in conflictual environments only when greener pastures are in sight, we add to this general argument that it is the relative attractiveness of political markets that matters for firms' strategic choices. Second, while previous studies on venue shopping by companies restricted their explanatory factors to the country level (Ehrlich and Jones 2016) and at the sector level (e.g. Bernhagen and Mitchell 2009), assuming that the partisan composition of national governments or the regulation of a particular sector affects all firm within that country, resp. sector, equally. We have relaxed this assumption to allow for the possibility that some firms within the same country and even sector may find policymakers more receptive to their concerns than others have. Thus, compared with the previous literature, in the present article we have gone one level deeper into the political circumstances surrounding individual firms, who may experience different interactions with policymakers than other firms within the same country and/or sector. Our empirical analysis investigates this at two levels, firm and country, including interactions between variables across the two levels. Third, while the analyses by Ehrlich and Jones (2016) as well as Bernhagen and Mitchell (2009) were restricted to using data on EU-level lobbying by companies, our survey data 
enables us to measure the relative importance of EU and national level lobbying as reported by companies' public affairs managers. Fourth, by examining venue choices of European firms across levels of government, we contribute to the empirical literature on multilevel governance as well as the venue shopping literature. To the former (e.g. Eising 2004), we add the insights about the national-level constraints on the fluidity of political advocacy. To the latter, we add new evidence on vertical venue shifts to a literature that has been dominated by analysis of horizontal shifts at one and the same level of government (cf. Holyoke et al. 2012).

Through our study's focus on the lobbying strategies of large businesses in the multilevel system, we have provided insights to the political activity of what are often considered the most economically powerful non-state actors in industrial democracies. These large internationally connected entities are the types of businesses that should have the ability to escape political context when they perceive the need to do so. Our analysis suggests that this ability is frequently put to use. However, firms' responses to deteriorating governmentbusiness relations in a particular venue are contingent on the institutional context. German firms place a bigger emphasis on EU lobbying compared with British firms. They are more readily willing to shift venues than British firms when national government-business relations deteriorate. However, under the right circumstances i.e. when EU-level government-business relations are perceived as being better than national-level relations, British firms are as ready to redeploy their lobby resources as their German peers. For the continued role of nationally distinct systems of interest representation, the sample of firms we analysed consists of least likely cases: Within their respective countries, these large firms are the least likely to be influenced by national legacies and patterns of interest representation. This provides us with confidence that the findings reported here would all be replicated if a sample of more and smaller firms were used.

Finally, while our country cases contain two EU member states, one of these is currently preparing to leave the EU. UK business actors have, on average, been strong supporters of the country's membership in the EU. We would expect that these actors will intensify their lobbying at both the national and EU level; to contain the damage incurred from 'Brexit' and to help secure single market membership for the UK. If the UK moved from EU membership 
to a status similar to EEA membership, its business actors can be expected to behave more like Norwegian or Swiss firms: they should intensify their lobbying activity in Brussels as they will no longer have a government patron at the table but still be subject to the common market rules. In the less likely scenario that the UK exits without single market membership status, we should also see increases in business lobbying activity in Brussels, analogous to US business lobbying there. Thus, after German firms have overtaken British firms in their readiness to shift lobby resources from the national to the EU level by the time the data for the present study have been collected, the future may see a reversal of this trend. Even at present, however, British firms are somewhat more active in lobbying at the foreign national level than are German firms. This reflects a stronger anchoring in foreign governance structures relative to EU governance, suggesting, in turn, that British firms' political strategy is relatively well suited for Brexit and its consequences. 
Figure 1. Distribution of the relative EU lobbying measure

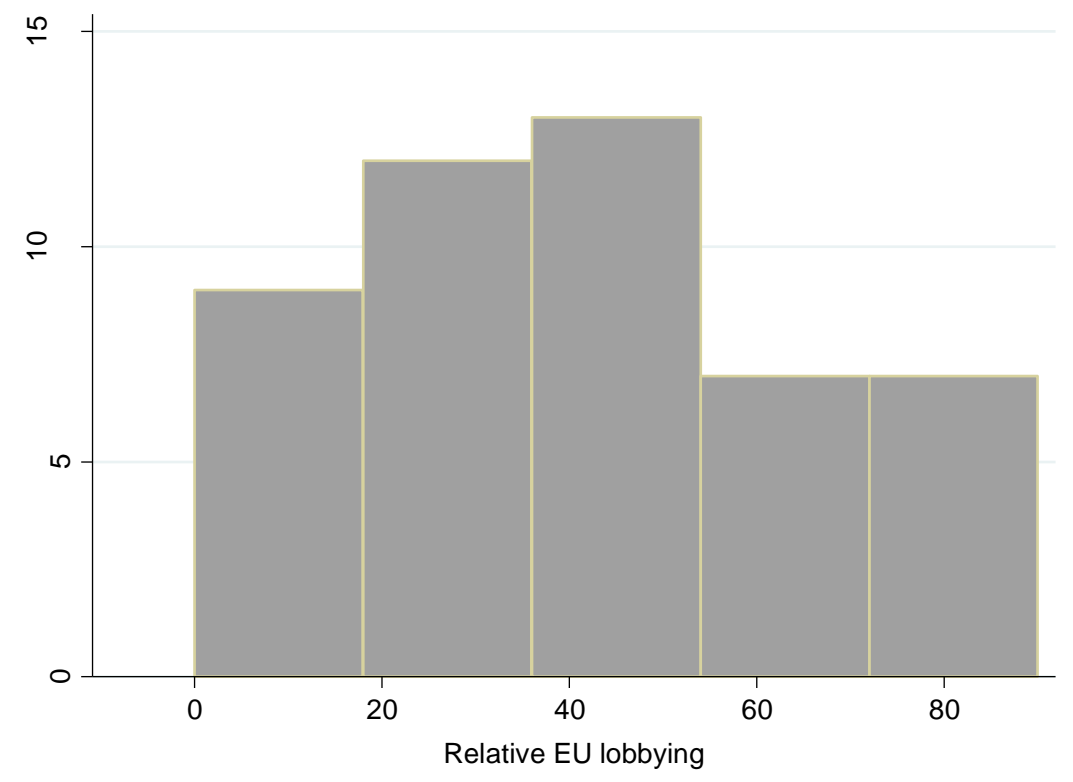

Figure 2. German and British firms' lobbying practise

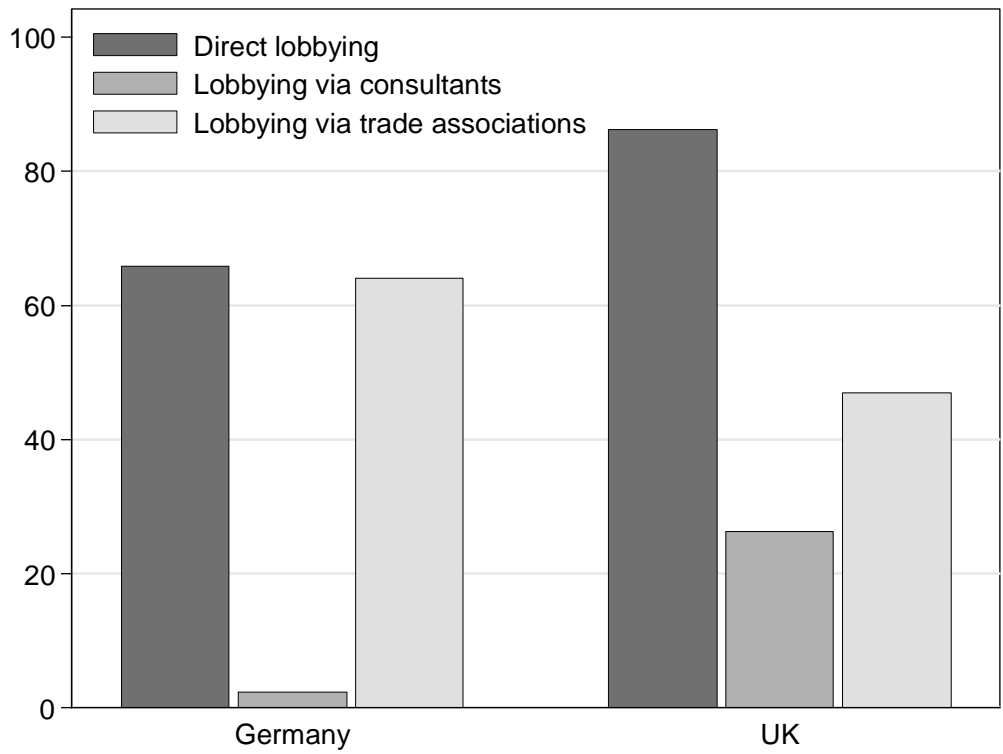

Note: the three within-country mean differences are statistically significant (t-test) at the 0.05 level: $n=54$ 
Figure 3. Lobbying across policy types

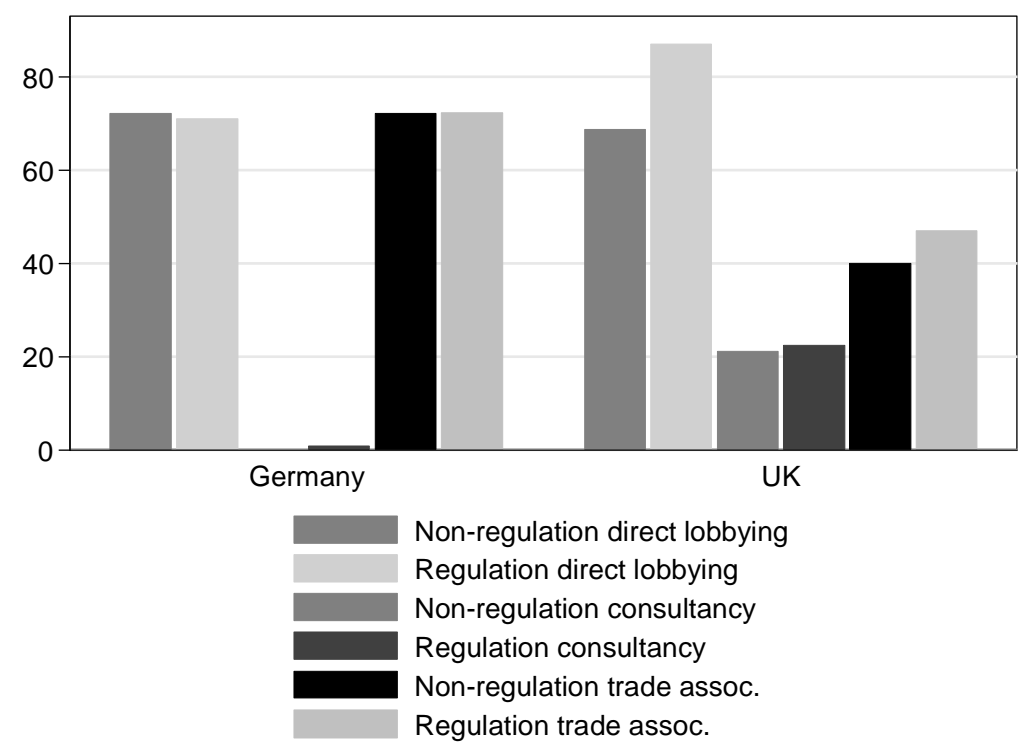

Note: The only significant $(<0.05)$ difference is between regulatory and non-regulatory lobbying: $n=54$

Figure 4. Comparing National \& EU lobbying

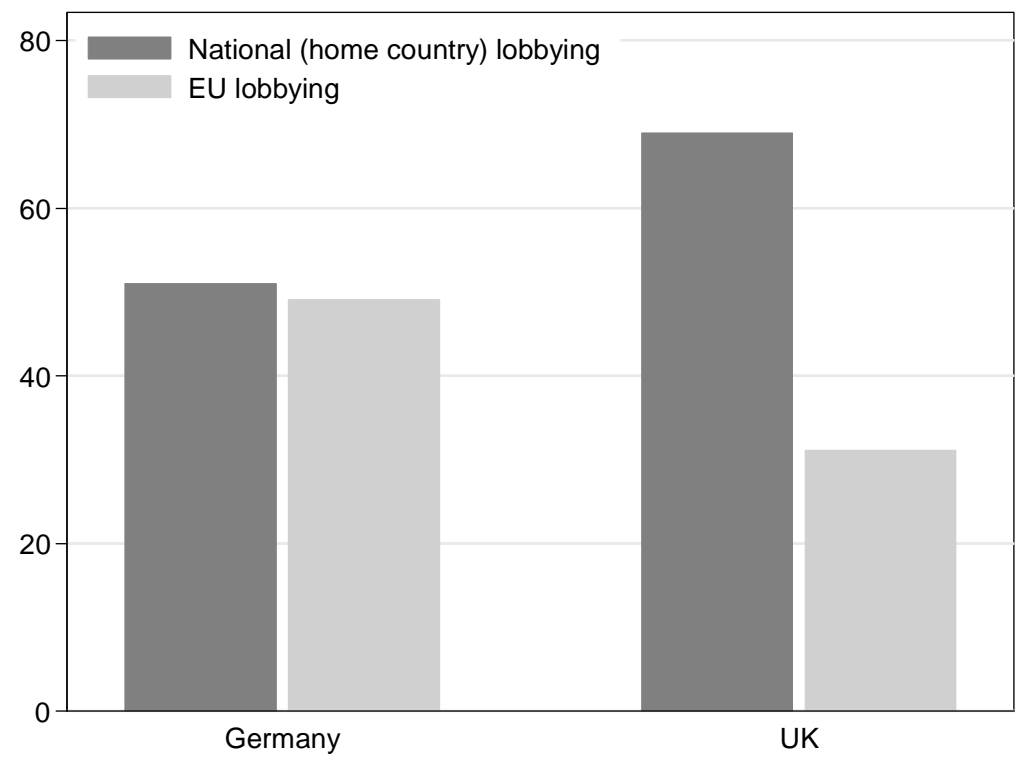

Note: difference in means between German and British firms are significant (t-test) at the 0.05 level: $n=56$ 
Figure 5. Comparing mean levels of conflict

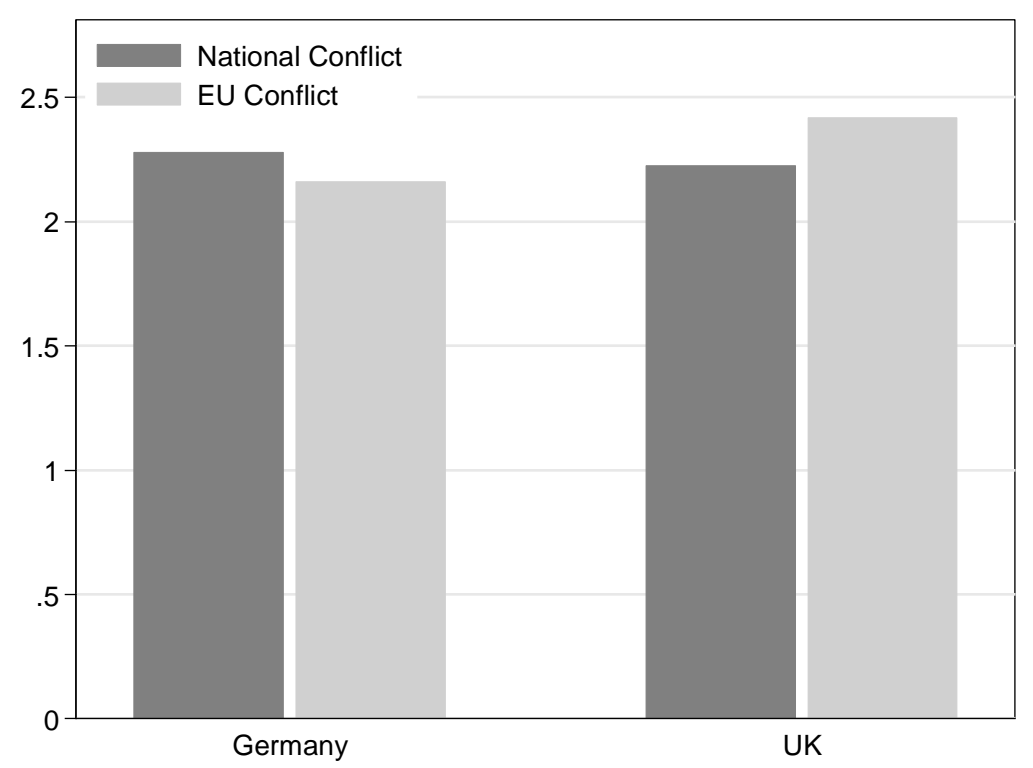

Note: difference in means between German and British firms are not significant: $\mathrm{n}=56$

Figure 6. Interaction of national conflict and country of headquarter

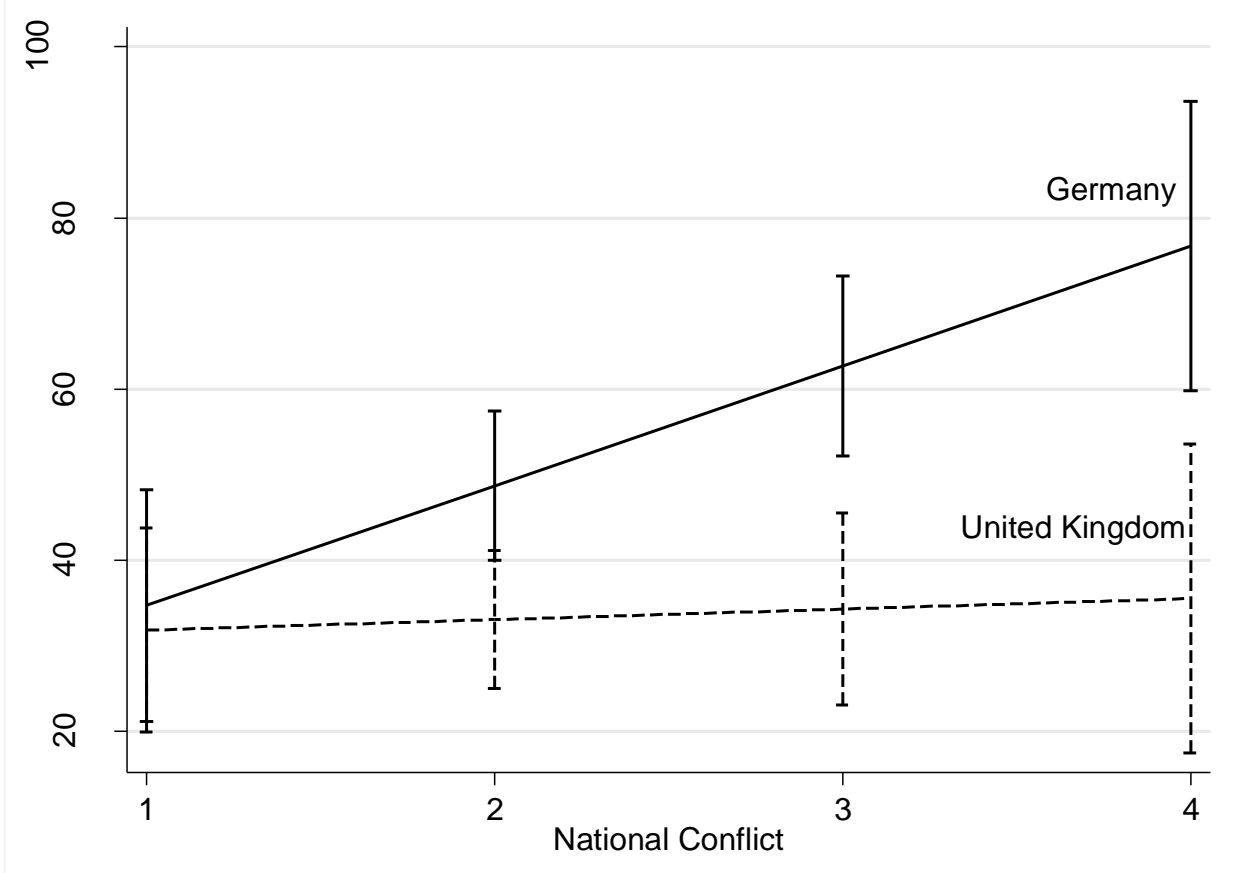


Figure 7. Interaction of relative conflict and country of headquarter

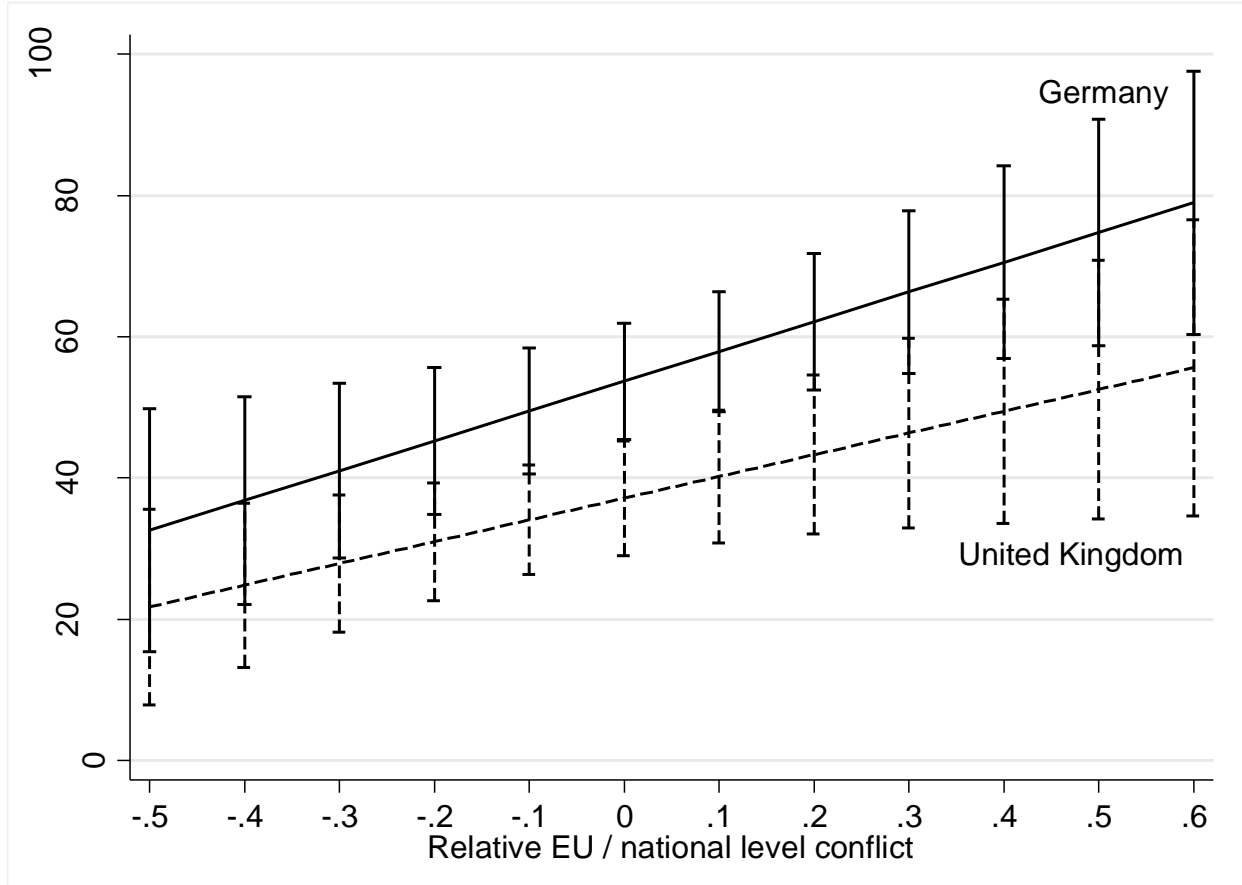

Table 1. Multivariate regression models of EU lobbying relative to national lobbying

\begin{tabular}{lccc} 
& Model 1 & Model 2 & Model 3 \\
\hline National Conflict & $8.296^{* * *}$ & $15.715^{* * *}$ & \\
& $(3.09)$ & $(4.54)$ & \\
Relative Conflict & & & $49.318^{* * *}$ \\
& & & $(11.33)$ \\
Country (UK) & $-21.453^{* * *}$ & 9.683 & $-18.655^{* * *}$ \\
& $(6.51)$ & $(15.75)$ & $(5.85)$ \\
Revenue (log) & 3.815 & $5.207^{*}$ & 4.61 \\
Financial sector & $(3.18)$ & $(2.73)$ & $(2.92)$ \\
& 7.09 & 3.198 & 0.32 \\
Foreign CPA & $(8.73)$ & $(7.93)$ & $(10.42)$ \\
& $0.544^{* *}$ & $0.555^{* *}$ & 0.304 \\
NatConflict*UK & $(0.24)$ & $(0.22)$ & $(0.28)$ \\
& & $-14.210^{* *}$ & \\
RelativeConflict*UK & & $(6.06)$ & \\
& & & -17.912 \\
constant & & & $(23.02)$ \\
& -12.476 & -42.36 & 4.67 \\
R-sqr & $(30.96)$ & $(31.15)$ & $(30.75)$ \\
$\mathrm{n}$ & & & \\
\hline
\end{tabular}

Note: Bootstrapped standard errors in parentheses.

$* p<0.1, * * p<0.05, * * * p<0.01$ 


\section{References}

Baumgartner, Frank R. and Bryan D. Jones (1991). 'Agenda Dynamics and Policy Subsystems'. Journal of Politics, 53:4, 1044-1074.

Baumgartner, Frank R. and Bryan D. Jones (1993). Agendas and Instability in American Politics. Chicago: University of Chicago Press.

Bennett, Robert J. (1997). 'The impact of European economic integration on business associations: The UK case'. West European Politics, 20:3, 61-90.

Bennett, Robert J. (1999). 'Business Routes of Influence in Brussels: Exploring the Choice of Direct Representation', Political Studies, 47:2, 240-57.

Bernhagen, Patrick, and Neil J. Mitchell (2009). 'The Determinants of Direct Corporate Lobbying in the European Union', European Union Politics, 10:2, 155-176.

Beyers, Jan, and Bart Kerremans (2012). 'Domestic embeddedness and the dynamics of multilevel venue shopping in four EU member states', Governance, 25:2, 263-90.

Boies, John L. (1989). 'Money, Business, and the State: Material Interests, Fortune 500 Corporations, and the Size of Political Action Committees', American Sociological Review, 54:5, 821-33.

Bonardi, Jean. P., Amy J. Hillman, and Gerald D. Keim (2005). 'The attractiveness of political markets: Implications for firm strategy', Academy of Management Review, 30(2): 397-413.

Chari, Raj S., and Francesco Cavatorta (2002). 'Economic Actors' Political Activity in "Overlap Issues2: Privatisation and EU State Aid Control', West European Politics, 25:4, 119142.

Coen, David (1997). 'The Evolution of the Large Firm as a Political Actor in the European Union', Journal of European Public Policy, 4:1, 91-108.

Coen, David (1998). 'European Business Interest and the Nation State: Large Firm Lobbying in the European Union and Member States', Journal of Public Policy, 18:1, 75-100.

Coen, David (2005). 'Managing Multilevel and Multi Institutional Regulation: A comparative study of Telecommunication Regulation in German and UK', Annals of Public and Cooperative Economics, 20:1, 59-84.

Cowles, Marie Green (1996). 'The EU Committee of AmCham: the powerful voice of American Firms in Brussels', Journal European Public Policy, 3:3: 339-58. 
Cowles, Maria Green (1998). 'The Changing Architect of Big Business', in Justin Greenwood and Mark Aspinwall (eds.) Collective Action in the European Union. London: Routledge.

Cowles, Maria Green (2001). 'The Transatlantic Business Dialogue and Domestic Businessgovernment Relations', in Maria Green Cowles, James A. Caporaso and Thomas Risse (eds), Transforming Europe: Europeanization and Domestic Change. Ithaca, NY: Cornell University Press, 159-79.

Crouch, Colin (1985). 'Conditions for trade union wage restraint', in L. N. Lindberg \& Ch. S. Maier (eds.), The Politics of Inflation and Economic Stagnation. Washington, DC: Brookings Institution, 105-139.

Dullforce, Anne-Britt (2015). FT 500 2015, Europe 500, Financial Times, available at http://www.ft.com/cms/s/2/a352a706-16a0-11e5-b07f-00144feabdc0.html \#axzz 46ewHEMQE (accessed 15 March 2016).

Ehrlich, Sean D. and Eryn Jones (2016). 'Whom do European corporations lobby? The domestic institutional determinants of interest group activity in the European Union', Business and Politics, 18:4, 467-488.

Eising, Rainer (2004). 'Multilevel Governance and Business Interests in the European Union', Governance, 17:2, 211-245.

Eising, Rainer, Danica Fink-Hafner, Mitja Hafner-Fink, Meta Novak, Daniel Rasch, and Patrycja Rozbicka (2017). 'Explaining the Participation of Domestic Interest Groups in National and EU level Consultations: Bringing in Arguments'. West European Politics, this volume.

Eurostat (2016). Gross domestic product at market prices, available at http://ec.europa.eu/eurostat/tgm/refresh (accessed 20 March 2016).

Falkner, Gerda (1998) EU Social Policy in the 1990s: Towards a corporatist policy community. European Public Policy Series. London, Routledge.

Granovetter, Mark (1992). 'Economic institutions as social constructions: a framework for analysis', Acta Sociologica, 35:1, 3-11

Grant, Wyn (1993). Business and Politics in Britain ( $2^{\text {nd }}$ ed.). London: Macmillan.

Greenwood, Justin (2003). Interest Representation in the European Union ( $2^{\text {nd }}$ ed.). London: Palgrave Macmillan. 
Greenwood, Justin (2007). 'Organized Civil Society and Democratic Legitimacy in the European Union', British Journal of Political Science, 37:2, 333-357.

Grier, Kevin B., Michael C. Munger and Brian E. Roberts (1994). 'The Determinants of Industry Political Activity, 1978-1986', American Political Science Review, 88:4, 91126.

Hansen, Wendy L., and Neil J. Mitchell (2000). 'Disaggregating and Explaining Corporate Political Activity: Domestic and Foreign Corporations in National Politics', American Political Science Review, 94:4, 891-903.

Hart, David (2004). "'Business" is not an interest group: On the Study of Companies in American National Politics, Annual Review of Political Science, 7, 47-69.

Hillman, Amy J., and Michael A. Hitt (1999). 'Corporate Political Strategy Formulation: A Model of Approach, Participation, and Strategy Decisions', The Academy of Management Review, 24:4, 825-842.

Hix, Simon (2005). The Political System of the European Union (2 ${ }^{\text {nd }}$ ed.), Basingstoke: Palgrave.

Holyoke, Thomas T., Heath Brown, and Jeffrey R. Henig (2012). 'Shopping in the Political Arena: Strategic State and Local Venue Shopping by Advocates', State and Local Government Review 44(April): 9-20.

Holyoke, Thomas T. (2003). 'Choosing Battlegrounds: Interest Group Lobbying Across 40 Multiple Venues', Political Research Quarterly 56(September): 325-336.

Kohler-Koch, Beate (1997). 'Organized Interests in the EC and the European Parliament', European Integration online Papers (EloP), 1:9.

Kohler-Koch, Beate, Peter Kotzian, and Christine Quittkat (2017). 'The Multi-Level Interest Representation of National Business Associations', West European Politics, this volume.

Lijphart, Arend (1999). Patterns of Democracy. Government Forms and Performance in Thirty-Six Countries. New Haven: Yale University Press.

Marks, Gary, and Liesbet Hooghe (2001). Multi-Level Governance and European Integration. Lanham: Rowman and Littlefield.

Marks, Gary, and Doug McAdam (1996). 'Social Movements and the Changing Structure of Political Opportunity in the European Union', West European Politics, 19:2, 249-78. 
Mazey, Sonia and Jeremy Richardson (1993). 'Interest group behaviour in the European Community: a European lobbying style?', in Jeremy Richardson (ed), Pressure Groups. Oxford: Oxford University Press, pp.191-213.

Mazey, Sonia and Jeremy Richardson (2001). 'Interest groups and EU policy-making: organisational logic and venue shopping, in: Jeremy Richardson (ed.)., European Union: Power and Policy-Making, London: Routledge 2001, 217-237.

Miller Warren E. (1999). 'Temporal Order and Causal Inference', Political Analysis, 8:2: 119146.

Pauly, Louis W. and Simon Reich (1997). 'National Structures and Multinational Corporate Behavior: Enduring Differences in the Age of Globalization', International Organization, 51: Winter, 1-30.

Poletti, Arlo, Dirk De Bièvre, and Marcel Hanegraaff (2016). 'WTO Judicial Politics and EU Trade Policy: Business Associations as Vessels of Special Interest?', British Journal of Politics \& International Relations, 18:1, 196-215.

Princen, Sebastiaan, and Bart Kerremans (2008). 'Opportunity Structures in the EU MultiLevel System', West European Politics, 31:6, 1129-1146.

Rasmussen, Anne, and Brendan J. Carroll (2014). 'Determinants of upper-class dominance in the heavenly chorus: Lessons from European Union online consultations', British Journal of Political Science, 44:2, 445-459.

Rehbein, Kathleen (1995). 'Foreign-owned Firms' Campaign Contributions in the United States: An Exploratory Study', Policy Studies Journal, 23:1, 41-61.

Siaroff, Alan (1999). 'Corporatism in 24 industrial democracies: Meaning and measurement', Journal of European Research, 36:2, 175-205.

Schmitter, Philippe C. (1974). 'Still the Century of Corporatism?', Review of Politics 36:1, 85131.

Stigler, George (1971). 'The Theory of Economic Regulation', Bell Journal of Economics and Management Science, 2:1, 3-21.

Streeck, Wolfgang and Philippe C. Schmitter (1991). 'From National Corporatism to Transnational Pluralism: Organizing Interests in the Single European Market', Politics and Society, 19:2, 133-64.

Vogel, David (1989). Fluctuating Fortunes: The Political Power of Business in America. New York: Basic Books.

Young, Alasdair and Helen Wallace (2000), Regulatory Politics in the Enlarging European 
Union. Manchester: Manchester University Press.

\footnotetext{
${ }^{1}$ Since our sample of from the UK includes no firms from Northern Ireland, in the remainder of the article we simply refer to 'British firms'.

${ }^{2}$ We initially sampled 100 companies from Germany and the UK, but increased the country-n to 104 and 107 , respectively, to compensate for low responses rates.

${ }^{3}$ Following established practice in the literature, size is measured by revenues in million US Dollars made during the financial year 2012. Profit is gross profit revenues in million US Dollars realized during 2012. Assets are total current assets of the corporation in million US Dollars in 2012, while the number of employees is the total number of employees of a corporation for that year.
}

${ }^{4}$ Other venues prompted are 'national governments of other countries in which your company has facilities, markets and / or suppliers, 'regional institutions (e.g. the European Union or NAFTA), 'international / global institutions (e.g. WTO, UN, UNCCC)', and 'international private standard-setting bodies (e.g. ISO or International Electrotechnical Commission)'.

${ }^{5}$ Firms are coded as within the 'financial sector' if their main activity falls within the SIC Code Division $\mathrm{H}$ ('Finance, insurance, \& real estate'). We have also estimated all models with a dummy variable indicating the manufacturing instead of the financial sector (together these two sectors comprise $56 \%$ of sample). This does not affect the substantive results reported here (see appendix A2). Due to limited degrees of freedom we present the theoretically more interesting findings controlling for financial sector.

${ }^{6}$ British firms are somewhat more active in lobbying at foreign national level than German firms. This reflects a stronger anchoring in foreign governance structures relative to EU governance.

${ }^{7}$ Respondents were asked, '[i]n the policy areas that you selected above, in which of the following ways did you express your position to policymakers?'. Responses are non-exclusive and comprise of 'approach policymakers directly ourselves', 'enlist the services of external consultants', 'work through a trade association', and 'other'. For this question we received 54 responses.

${ }^{8}$ Here and in Figure 2, a mean of 1 would indicate that all firms adopt a particular mode of lobbying, whereas a value of 0 would suggest that none of them do. 


\section{Appendix}

Table A1. Summary statistics

\begin{tabular}{lccccc}
\hline Variable & $\mathrm{N}$ & Mean & Std. Dev. & Min. & Max. \\
Relative EU lobbying & 48 & 41.7 & 25.2 & 0 & 90 \\
Relative National lobbying & 50 & 59.9 & 26.1 & 10 & 100 \\
National conflict & 56 & 2.25 & 1 & 1 & 4 \\
EU conflict & 56 & 2.3 & 0.9 & 1 & 4 \\
Relative conflict & 51 & 0 & 0.3 & -0.6 & 0.6 \\
Revenue (data logged) & 56 & 9.4 & 1.1 & 6.2 & 11.5 \\
Financial sector & 56 & 0.15 & 0.36 & 0 & 1 \\
Foreign CPA & 51 & 19 & 14.5 & 0 & 75 \\
Direct lobbying & 54 & 0.79 & 0.42 & 0 & 1 \\
Lobbying via consultant & 54 & 0.15 & 0.35 & 0 & 1 \\
Lobbying via trade assoc. & 54 & 0.59 & 0.51 & 0 & 1 \\
\hline
\end{tabular}

Table A2. Multivariate regression models of EU lobbying relative to national lobbying, with financial sector replaced with manufacturing sector

\begin{tabular}{lccc} 
& Model 1 & Model 2 & Model 3 \\
\hline National Conflict & $7.694^{* *}$ & $14.959^{* * *}$ & \\
& $(-3.85)$ & $(-3.76)$ & \\
Relative Conflict & & & $47.627^{* * *}$ \\
& & & $(-12.27)$ \\
Country (UK) & $-17.903^{* * *}$ & 12.131 & $-15.876^{* * *}$ \\
& $(-6.79)$ & $(-13.61)$ & $(-5.82)$ \\
Revenue (log) & 2.039 & 3.886 & 3.572 \\
& $(-3.33)$ & $(-3.301)$ & $(-2.56)$ \\
Manufacturing sector & 10.886 & 9.767 & 9.506 \\
& $(-7.53)$ & $(-5.48)$ & $(-6.02)$ \\
Foreign CPA & $0.380^{*}$ & $0.431^{*}$ & 0.213 \\
& $(-0.23)$ & $(-0.33)$ & $(-0.23)$ \\
NatConflict*UK & & $-14.009 * * *$ & \\
& & $(-6.06)$ & \\
RelativeConflict*UK & & & -16.858 \\
& & & $(-19.62)$ \\
constant & 3.41 & -31.068 & 10.514 \\
& $(-32.1)$ & $(-31.15)$ & $(-25.97)$ \\
R-sqr & & & \\
$\mathrm{n}$ & 0.4 & 0.47 & 0.5 \\
\hline
\end{tabular}

Note: Bootstrapped standard errors in parentheses.

$* \mathrm{p}<0.1, * * \mathrm{p}<0.05, * * * \mathrm{p}<0.01$ 